\title{
Manifestasi Oral Infeksi COVID-19
}

\author{
Yobel R. Woran, ${ }^{1}$ Lydia E. N. Tendean, ${ }^{2}$ Christy N. Mintjelungan ${ }^{1}$
}

\author{
${ }^{1}$ Program Studi Pendidikan Dokter Gigi Fakultas Kedokteran Universitas Sam Ratulangi, \\ Manado, Indonesia \\ ${ }^{2}$ Bagian Biologi Fakultas Kedokteran Universitas Sam Ratulangi, Manado, Indonesia \\ Email: yobelworan013@student.unsrat.ac.id
}

\begin{abstract}
The COVID-19 outbreak is caused by SARS-CoV-2 that spread rapidly throughout the world. The most common clinical manifestations of COVID-19 are fever, fatigue, and dry cough. Some patients experience nasal congestion, runny nose, headache, conjunctivitis, sore throat, diarrhea, skin rash, loss of smell and taste. Oral manifestations of COVID-19 infection are also reported. Dentists are prone to cross-infections of several infectious diseases because they are often exposed to saliva and blood. These viruses are transmitted through inhalation of aerosols and droplets containing the viruses or direct contact with mucous membranes, oral fluids, dental instruments, and surfaces contaminated with the virus. This study was aimed to determine the oral manifestations of COVID-19 infection. This was a literature review study searching three databases, namely Pubmed, ClinicalKey and Google Scholar. The keywords used were oral AND manifestations AND COVID-19. Selection based on inclusion and exclusion criteria was carried out by critical appraisal. There were eight literatures in the form of case reports. The results showed that oral manifestations commonly found in patients with clinical COVID-19 were ulcers, petechiae, macules, and plaques with variations in quantity, color appearance, and localization. Lesions were found on the palate, tongue, labial mucosa, gingiva, lips, and oropharynx. In conclusion, oral manifestations could be found in clinical COVID-19 patients, however, it is not certain whether these manifestations are directly caused by SARS-CoV-2 or are as secondary manifestations.
\end{abstract}

Keywords: oral manifestations; COVID-19

\begin{abstract}
Abstrak: Wabah COVID-19 disebabkan oleh SARS-CoV-2 yang menyebar dengan cepat hingga ke seluruh dunia. Infeksi COVID-19 mempunyai manifestasi klinis paling umum seperti demam, rasa lelah, dan batuk kering. Beberapa pasien mengalami hidung tersumbat, pilek, nyeri kepala, konjungtivitis, sakit tenggorokan, diare, ruam kulit, hilang penciuman dan pengecapan. Bahkan terdapat laporan penemuan manifestasi oral pada infeksi COVID-19. Dokter gigi sebagai profesi yang rentan terjadi infeksi silang beberapa penyakit menular karena sering terpapar dengan saliva dan darah. Virus ini memungkinkan terjadinya penularan lewat terhirupnya aerosol dan droplet yang mengandung virus atau kontak langsung dengan membran mukosa, cairan mulut, instrumen kedokteran gigi dan permukaan yang terkontaminasi virus. Penelitian ini bertujuan untuk mengetahui manifestasi oral infeksi COVID-19. Jenis penelitian ialah suatu literature review dengan pencarian menggunakan tiga database yaitu Pubmed, ClinicalKey dan Google Scholar. Kata kunci yang digunakan yaitu oral AND manifestations AND COVID-19. Setelah seleksi berdasarkan kriteria inklusi dan ekslusi dilakukan critical appraisal dan didapatkan delapan literatur yang berupa laporan kasus. Hasil penelitian mendapatkan bahwa manifestasi oral pada pasien klinis COVID-19 yang sering ditemukan, seperti ulkus, petekie, makula, dan plak dengan variasi kuantitas, penampakan warna, dan lokalisasi. Lokasi lesi ditemukan pada palatum, lidah, mukosa labial, gingiva, bibir dan orofaring. Simpulan penelitian ini ialah manifestasi oral dapat ditemukan pada pasien klinis COVID-19 tetapi belum diketahui pasti apakah secara langsung disebabkan oleh SARS-CoV-2 atau merupakan manifestasi sekunder.
\end{abstract}

Kata kunci: manifestasi oral; COVID-19 


\section{PENDAHULUAN}

Pada tanggal 11 bulan Maret tahun 2020, Organisasi Kesehatan Dunia atau World Health Organization (WHO) mengumumkan status pandemi coronavirus disease 2019 (COVID-19). Wabah COVID19 disebabkan oleh severe acute respiratory syndrome coronavirus 2 atau sindrom pernapasan akut yang parah coronavirus 2 (SARS-CoV-2). COVID-19 merupakan infeksi virus jenis baru yang pertama kali ditemukan di Wuhan, China pada bulan Desember 2019. Virus baru ini menyebar dengan cepat hingga ke seluruh dunia. ${ }^{1}$

Coronavirus adalah virus dengan untai tunggal RNA, nonsegmented, diselubungi oleh pembungkus (enveloped), yang menyebabkan penyakit mulai dari flu biasa sampai penyakit yang fatal. Istilah Coronavirus berasal dari kata Latin corona, yang berarti mahkota atau halo. Sebutan itu muncul dari penampilan virion coronavirus saat dilihat dengan mikroskop elektron, di mana partikel virus menampilkan pinggiran seperti mahkota. $^{2}$

Kasus COVID-19 di Indonesia pertama kali dilaporkan pada tanggal 2 Maret 2020 dan per 19 Oktober 2020 kasus positif COVID-19 di Indonesia sudah mencapai 361.867 kasus terkonfirmasi, 285.324 $(78,8 \%)$ kasus sembuh, dan 13.511 (3,5\%) meninggal dunia, serta 500 Kabupaten/Kota telah terdampak. ${ }^{3}$

Infeksi COVID-19 mempunyai manifestasi klinis paling umum seperti demam, rasa lelah, dan batuk kering. Beberapa pasien mungkin mengalami rasa nyeri dan sakit, hidung tersumbat, pilek, nyeri kepala, konjungtivitis, sakit tenggorokan, diare, hilang penciuman dan pembauan, atau ruam kulit. Namun tidak semua yang terinfeksi COVID-19 memiliki gejala-gejala yang telah disebutkan tadi, bahkan terdapat individu yang tak bergejala (asimtomatik). ${ }^{1}$ Berdasarkan laporan kasus di Prancis pada April 2020, Chaux-Bodard et $\mathrm{al}^{4}$ menemukan manifestasi klinis lain pada pasien COVID-19 yakni terdapat ulser pada dorsal lidah pasien yang terinfeksi COVID-19.

Pandemi COVID-19 ini berpengaruh sangat besar terhadap berbagai profesi kesehatan, termasuk diantaranya profesi dokter gigi. Profesi dokter gigi merupakan profesi yang rentan terjadi infeksi silang beberapa penyakit menular karena sering terpapar dengan saliva dan darah. ${ }^{5}$ SARSCoV-2, virus yang menyebabkan COVID19 ini juga memungkinkan terjadinya penularan di praktik kedokteran gigi karena adanya kemungkinan terhirup aerosol atau droplet yang mengandung virus atau kontak langsung dengan membran mukosa, cairan mulut, serta instrumen dan permukaan yang terkontaminasi virus. ${ }^{6}$

Oleh karena itu penting dipahami manifestasi oral infeksi COVID-19 mengingat rongga mulut atau oral merupakan ranah kerja utama bagi dokter gigi. Menemukan sedini mungkin bila terdapat manifestasi oral infeksi COVID-19 pada pasien tanpa gejala utama dapat menjadi peringatan awal bagi dokter gigi dalam praktik klinis.

Berdasarkan latar belakang tersebut, penulis tertarik melakukan penelitian literature review untuk membahas dan menelaah berbagai informasi ilmiah mengenai manifestasi oral infeksi COVID-19.

\section{METODE PENELITIAN}

Penelitian ini dilakukan pada bulan Desember 2020-April 2021. Jenis penelitian ialah suatu literature review. Data penelitian ialah data sekunder yang diperoleh dari tiga database dengan kriteria yang ditentukan yaitu Pubmed, ClinicalKey, dan Google Scholar. Kata kunci yang digunakan dalam pencarian artikel yaitu oral AND manifestations AND COVID-19. Kriteria inklusi dalam penelitian ini yakni: artikel terbitan 2020 sampai 2021, berbahasa Indonesia dan Inggris, sampel penelitian merupakan seseorang yang terinfeksi COVID-19 dengan manifestasi oral, serta jenis penelitian case report, case control study, cross-sectional study dan cohort study. Artikel yang tidak tersedia fulltext dieksklusikan.

\section{HASIL PENELITIAN}

Berdasarkan hasil pencarian pustaka, didapatkan artikel sebanyak 67 mengguna- 
kan PubMed, 11 menggunakan ClinicalKey, dan 8370 menggunakan Google Scholar $(\mathrm{n}=8448)$ yang sesuai dengan kata kunci tersebut. Hasil pencarian kemudian dilakukan skrining berdasarkan judul yang sesuai dengan tema studi pustaka dan didapatkan 51 artikel $(n=51)$. Selanjutnya 51 artikel tersebut diskrining abstrak dan fulltext berdasarkan kriteria inklusi dan ekslusi sehingga didapatkan delapan artikel $(n=8)$.
Critical appraisal dilakukan pada delapan artikel yang memenuhi kriteria kelayakan dan yang digunakan dalam penelitian ini. Hasil telaah ini diaudit oleh pakar yang memahami topik yang diteliti dalam literature review ini

Tabel 1 menampilkan manifestasi oral serta lokasi ditemukannya pada setiap laporan kasus dalam artikel.

Tabel 1. Manifestasi oral dan lokasinya pada masing-masing literature

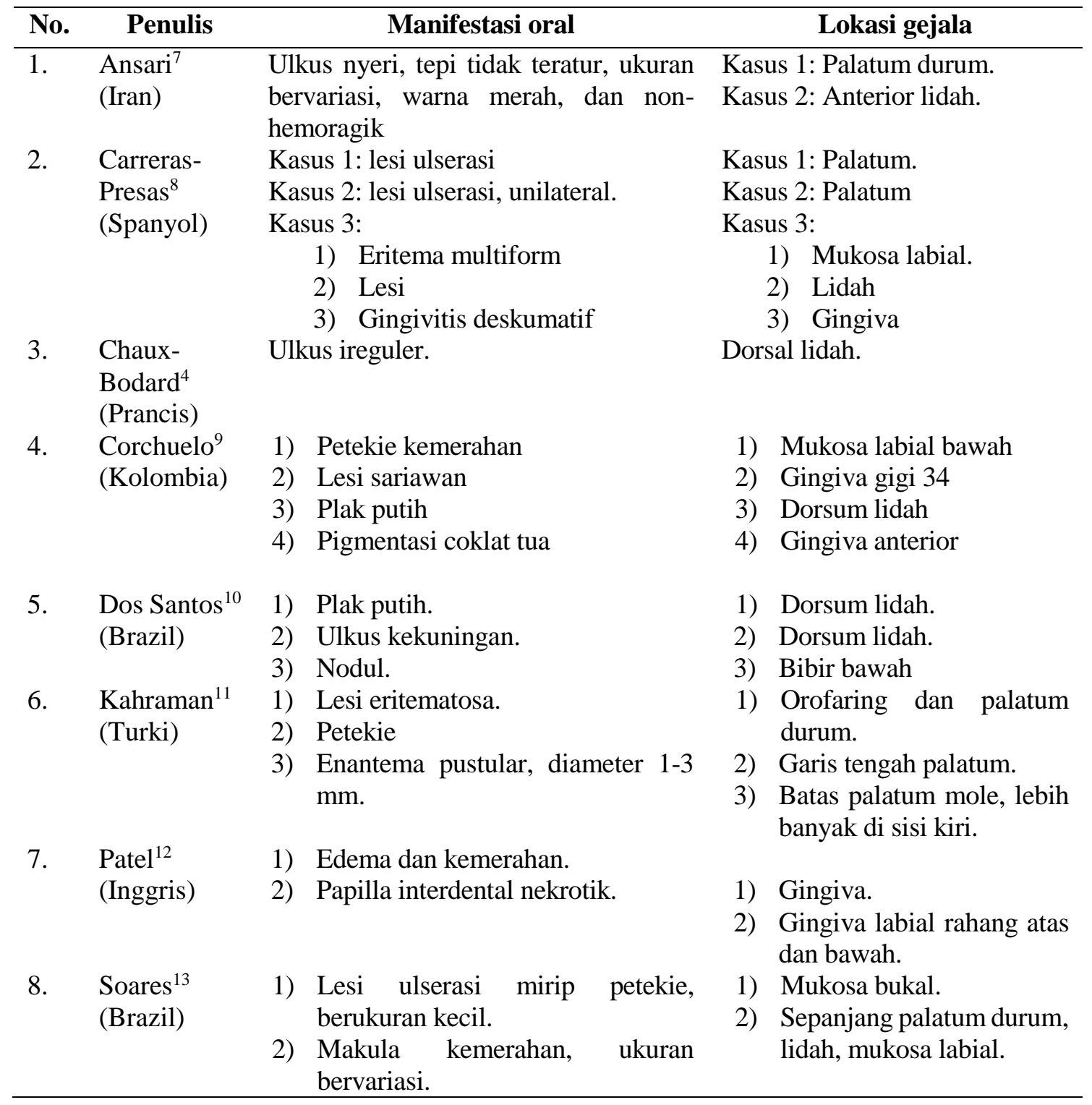

Tabel 2 memperlihatkan distribusi manifestasi klinis oral yang ditemukan. Manifestasi klinis oral yang paling banyak ditemukan ialah berupa lesi berbentuk ulkus sebanyak tujuh kasus, eritema empat kasus, petekie dua kasus, plak putih dua kasus, gingivitis dua kasus, makula dan pigmentasi masing-masing satu kasus, serta lesi lainnya 
sebanyak enam kasus.

Tabel 1. Distribusi manifestasi klinis oral yang ditemukan

\begin{tabular}{llcc}
\hline No & Manifestasi & \multicolumn{2}{c}{ Jumlah lesi } \\
\cline { 3 - 4 } & klinis oral & n & \% \\
\hline 1 & Ulkus & 7 & $28 \%$ \\
2 & Eritema & 4 & $16 \%$ \\
3 & Petekie & 2 & $8 \%$ \\
4 & Plak putih & 2 & $8 \%$ \\
5 & Gingivitis & 2 & $8 \%$ \\
6 & Makula & 1 & $4 \%$ \\
7 & Pigmentasi & 1 & $4 \%$ \\
8 & Lesi lainnya & 6 & $24 \%$ \\
\hline
\end{tabular}

Tabel 3 memperlihatkan distribusi lokasi lesi yang ditemukan. Lokasi terbanyak ditemukannya lesi yaitu pada palatum dan lidah masing-masing ditemukan tujuh kasus, gingiva lima kasus, mukosa oral empat kasus, serta bibir dan orofaring masing-masing satu kasus.

Tabel 3. Distribusi lokasi lesi yang ditemukan

\begin{tabular}{clcc}
\hline No & Lokasi lesi & \multicolumn{2}{c}{ Jumlah lesi } \\
\cline { 3 - 4 } & & n & \% \\
\hline 1 & Lidah & 7 & $28 \%$ \\
2 & Palatum & 7 & $28 \%$ \\
3 & Gingiva & 5 & $20 \%$ \\
4 & Mukosa oral & 4 & $16 \%$ \\
5 & Bibir & 1 & $4 \%$ \\
6 & Orofaring & 1 & $4 \%$ \\
\hline
\end{tabular}

\section{BAHASAN}

Manifestasi oral pasien yang terinfeksi COVID-19 berupa lesi mukosa oral hanya dijelaskan dalam beberapa laporan kasus, sehingga berdasarkan literatur yang diperoleh belum dapat disimpulkan apakah kondisi ini secara langsung disebabkan oleh SARS-CoV-2 atau merupakan manifestasi sekunder. ${ }^{4,7-13}$

Meskipun demikian, manifestasi oral yang ditemukan menunjukkan aspek klinis yang bermacam-macam, seperti ulkus, petekie, makula, dan plak, dengan variasi kuantitas, penampakan warna, dan lokalisasi. Pola lesi mukosa yang berbeda terkait dengan satu virus jarang terjadi, namun hipotesis akibat kondisi sistemik, penurunan daya tahan tubuh, serta tingkat stres akibat positif terinfeksi COVID-19 sehingga menyebabkan koinfeksi lesi mukosa oral seperti infeksi berulang herpes pada pasien yang dilaporkan oleh Dos Santos di Brazil. Kondisi demikian menekankan pentingnya penelitian lebih lanjut apakah lesi yang ditemukan merupakan koinfeksi yang berhubungan dengan infeksi SARS-Cov2. ${ }^{10}$

Selain karena koinfeksi, respon inflamasi akibat infeksi COVID-19 juga dicurigai menyebabkan timbulnya manifestasi oral. Laporan kasus Chaux-Bodard et $\mathrm{al}^{4}$ di Prancis mengaitkan lesi oral yang ditemukan pada pasiennya sebagai respon inflamasi akibat infeksi COVID-19. Laporan kasus Corchuelo dan Ulloa $^{9}$ di Kolombia juga mengaitkan pigmentasi gingiva pada pasiennya terkait dengan infeksi COVID19. Pigmentasi sering terjadi pada ras Afro dan pada kasus tersebut terjadi karena proses inflamasi sebagai respons infeksi SARS-CoV-2 yang dapat menyebabkan proliferasi melanosit di bagian tubuh tersebut.

Sebelas pasien dari delapan artikel menunjukkan lesi oral yang bervariasi serta lokasi lesi yang berbeda-beda. Lokasi gejala terbanyak ditemukan di palatum pada tujuh kasus dan di lidah pada tujuh kasus baik anterior lidah maupun dorsal lidah. Selain pada palatum dan lidah, beberapa lesi juga ditemukan pada mukosa oral, gingiva, bibir dan orofaring. Oleh karena itu, belum dapat disimpulkan apakah infeksi COVID-19 sebagai penyebab munculnya lesi yang bermanifestasi di lokasi tertentu pada rongga mulut. ${ }^{4,7-13}$

Studi mencatat koinfeksi bakteri dan jamur pada banyak kasus COVID-19 yang fatal. Dalam artikel dijelaskan pasien yang dirawat sering menerima antibiotik; namun, tidak ada spesifikasi tentang sensitivitas bakteri. Selain itu, sebagian besar pasien menunjukkan bahwa munculnya lesi mukosa oral terjadi selama masa rawat inap, yang mendukung hipotesis adanya koinfeksi, gangguan kekebalan, atau reaksi merugikan dari pengobatan COVID-19. Dalam hal ini, pemeriksaan oral pada pasien COVID-19 tidak boleh diabaikan dan pen- 
tingnya pemeriksaan klinis oral pasien penyakit infeksi di unit perawatan intensif perlu disosialisasikan., ${ }^{4-13}$

Jumlah penelitian serta bukti kepastian yang masih rendah mengenai lesi mukosa oral pada pasien dengan COVID-19 dan etiopatogenesisnya. Berbagai aspek klinis menunjukkan bahwa koinfeksi, penurunan kekebalan, dan reaksi mukosa oral terutama disebabkan oleh SARS-CoV-2.

\section{SIMPULAN}

Manifestasi oral pada pasien yang terinfeksi COVID-19 dengan aspek klinis yang sering ditemukan ialah: ulkus, petekie, makula, dan plak dengan variasi kuantitas, penampakan warna, dan lokalisasi. Lokasi lesi ditemukan pada palatum, lidah, mukosa oral, gingiva, bibir dan orofaring. Belum dapat disimpulkan apakah manifestasi oral ini secara langsung disebabkan oleh SARSCoV-2 atau merupakan manifestasi sekunder. ${ }^{4-13}$

\section{Konflik Kepentingan}

Penulis menyatakan tidak terdapat konflik kepentingan dalam studi ini.

\section{DAFTAR PUSTAKA}

1. Direktorat Jenderal Pencegahan dan Pengendalian Penyakit (P2P). Pedoman Pencegahan dan Pengendalian Coronavirus Disease (COVID-19) (Revisi ke5). Jakarta: Kementerian Kesehatan RI, 2020; p. 19-24.

2. Shereen MA, Khan S, Kazmi A, Bashir N, Siddique R. COVID-19 infection: origin, transmission, and characteristics of human coronaviruses. J Adv Res. 2020; 24(1):91-8.

3. Kementerian Kesehatan RI. Update Kasus 19 Oktober 2020. [Internet]. Indonesia. 2020. [cited 2020 Oct 19]. Available from: https://covid19.kemkes.go.id/

4. Chaux-Bodard A, Deneuve S, Desoutter A. Oral manifestation of COVID-19 as an inaugural symptom? J Oral Med Oral Surg. 2020;26(1):18.

5. Laheij AMGA, Belibasakis GN, Vakimaa H, de Soet JJ. Healthcare-associated viral and bacterial infections in dentistry. $\mathrm{J}$ Oral Microbiol. 2020;4(1):1-10.

6. Chen N, Zhou M, Dong X, Qu J, Gong F, Han $\mathrm{Y}$, et al. Epidemiological and clinical characteristics of 99 cases of 2019 novel coronavirus pneumonia in Wuhan, China: a descriptive study. Lancet. 2020;395(10223):1-7.

7. Ansari R, Gheitani M, Heidari F. Oral cavity lesions as a manifestation of the novel virus (Covid-19): a letter-to-editor. J Oral Dis. 2020;27(1):771-2.

8. Carreras-Presas M, Sanchez JA, LopezSanchez F, Jane-Salas E, Perez MLS. Oral vesiculobullous lesions associated with SARS-CoV-2 infection. J Oral Dis. 2021;27(Suppl 3):710-2.

9. Corchuelo J, Ulloa FC. Oral manifestations in a patient with a history of asymptomatic covid-19: case report. Int J Infect Dis. 2020;100(1):154-7.

10. Dos Santos JA, Normando AGC, da Silva RLC, De Paula RM, Cembranel AC, Santos-Silva AR, et al. Oral mucosal lesions in a Covid-19 patients: new signs or secondary manifestations. Int $\mathrm{J}$ Infect Dis. 2020;97(1):326-8.

11. Kahraman FC, Caskurlu H. Mucosal involvement in a covid-19-positive patient: a case report. J Dermatol Ther. 2020; 33(4): e13797.

12. Patel J, Woolley J. Necrotizing periodontal disease: oral manifestation of covid-19. J Oral Dis. 2020;10.1111/odi.13462.

13. Soares CD, de Carvalho RA, de Carvalho KA, de Carvalho MGF, de Almeida OP. Letter to editor: oral lesions in a patient with covid-19. J Medicina Oral. 2020; 25(4):e563. 